\title{
ОБҐРУНТУВАННЯ МЕХАНІЗМІВ ОПТИМІЗАЦІЇ ТЕХНОЛОГО-ЕКОНОМІЧНИХ ПАРАМЕТРІВ МОЛОЧНИХ ФЕРМ I КОМПЛЕКСІВ РІЗНОЇ ВИРОБНИЧОЇ ПОТУЖНОСТІ
}

\author{
Марченко Валерій Анатолійович \\ кандидат економічних наук, старший науковий співробітник \\ Інститут тваринництва НААН \\ ORCID: 0000-0002-9739-4987 \\ e-mail: vlsnitv8@gmail.com
}

Корх Ігор Володимирович кандидат сільськогосподарських наук, ст. науковий співробітник Інститут тваринництва НААН ORCID: 0000-0002-8077-895X e-mail: dr.fox2011@ukr.net

\author{
Петраш Вікторія Станіславівна \\ кандидат сільськогосподарських наук \\ Інститут тваринництва НАAН \\ ORCID: 0000-0001-9114-6117 \\ e-mail: petrash.vs@gmail.com
}

Ткачов Анатолій Валерійович
aспірант
Iнститут тваринництва HAAH
ORCID: 0000-0002-6325-4724
e-mail: talyan.tkachov@gmail.com

В матеріалах статті наголошено про необхідність розвитку тваринниитва в умовах його деградації, наведено фоктичні статистичні дані, які ілюструють негативні тенденції розвитку всієї галузі за останній період. Матеріали статті розкривають основні моменти проблеми, що пов'язана зі змінами технологічних параметрів підприємств різної виробничої потужності. Ці зміни стосуються, у першу чергу, нерівномірного варіювання усіх видів витрат ресурсів у грошовому виразі навіть у межах групувань підприємств відносно однакових показників виробництва. Складність проблеми поглиблюється і тим, що за різних технологічних переоснащень зміни витрат носять складний характер кореляційних зв'язків між собою. Визначеними фракторами-лідерами впливу на загальні витрати стали продуктивність, поголів'я корів та сума змінних витрат, основна значущість серед яких належить витратам на корми. На матеріалах фактичних даних виробників молока Харківської області за розробленою авторами методикою оптимізації технологоекономічних параметрів підприємств різної виробничої потужності визначені і наведені функціональні залежності загальних витрат від продуктивності корів, чисельності поголів'я і змінних витрат. Механізм оптимізації технологоекономічних параметрів полягає у наведених рівняннях множинної нелінійної регресії для підприємств з виробництвом до 20 тис. и молока в рік (мала виробнича потужність), від 20 до 60 тис. и (середня) і підприємств великої потужності - від 60 до 100 тис. и. молока в рік, які дають можливість універсально оцінювати і обчислювати закономірності взаємодії впливових чинників, отримувати їх кількісні характеристики у межах градації відповідної потужності підприємств. Коефіцієнт множинної кореляції між впливовими ознаками (продуктивність, чисельність поголів'я і змінні витрати) відповідно становить Rмн.=0,784404; Rмн.=0,966271 та Rмн.=0,56011. Середня відносна помилка апроксимації дорівнює 10,1\%; 10,5 \% і 13,9 \% відповідно. Наведений методичний підхід розкриває принципи механізмів щодо вирішення проблем оптимізації технологічних параметрів через багатофракторні нелінійні функиіональні залежності шляхом створення адекватних моделей прогнозування з подальшою мінімізацією змінних витрат за необхідної встановленої потужності.

Ключові слова: виробнича потужність, витрати ресурсів, модель прогнозування, оптимізація параметрів, продукція тваринництва.

DOI: https://doi.org/10.32845/bsnau.Ivst.2019.1-2.12

Розвиток тваринництва в Україні є важливою умовою продовольчої безпеки, сталого соціально-економічного стану держави та істотним резервом експорту сільськогосподарської продукції. Характерною рисою галузі $\epsilon$ те, що вона функціонує у великому діапазоні - від промислового до натурального виробництва. Незважаючи на певні економічні важелі щодо стимулювання виробництва продукції тваринництва та досягнення зоотехнічної науки, стан справ у колись потужній в Україні галузі постійно погіршується, особ-

ливо в останні роки [1]. Стабілізація і подальший розвиток виробництва окрім загальної стратегії і концепції неможливі без чіткого розуміння власне самих механізмів побудови виробничих процесів в умовах інноваційних технологічних рішень. Тому, для вирішення проблеми проведено дослідження зі встановлення взаємозалежностей та обгрунтування механізмів оптимізації технолого-економічних параметрів моделей молочних ферм і комплексів різної виробничої потужності (№ держреєстрації 0116U002315).

Вісник Сумського національного аграрного університету 
Останні тенденції діяльності тваринництва як галузі в цілому свідчать про хронічне скорочення загальної чисельності поголів'я сільськогосподарських тварин по всіх категоріях господарств (табл. 1). Відповідно на цьому фоні спостерігається зменшення і обсягів виробництва продукції, що викликає занепокоєння 3 точки зору забезпечення готовою продукцією ринку, сировиною суміжні галузі переробки, а сільські території - умовами соціального характеру - працевлаштування, збереження інфраструктури тощо [1, 2].

Аналіз лінійної загальної тенденції зміни чисельності поголів'я ВРX за 2015-2019 рр. свідчить про щорічне його зменшення в середньому на 3050 голів за рік. При цьому кількість корів в середньому скорочується по 1350 голів за рік (як, наприклад, ціле господарство ДП ДГ «Кутузівка» Харківської обл.).

Будь-яке виробництво продукції пов'язано із витратами різних видів ресурсів. Від ефективності їх використання залежить економічний результат діяльності. Водночас для підвищення прибутковості головною метою $є$ не максимальне зниження (чи досягнення) витрат на виробництво, а насамперед оптимальне, тобто таке, яке б забезпечило отри- мання підприємством запланованої суми прибутку. Ось чому, з метою раціональної побудови технологічного процесу виробництва продукції тваринництва і якомога оптимального зниження витрат, необхідно глибоко ураховувати їх взаємозв'язки за усіма напрямами.

Попередні дослідження на основі маловитратних технологій виробництва молока для малих (з поголів'ям 20 і 50 корів) і великотоварних господарств (1000 корів) дозволили розробити їх організаційно-виробничі параметри за умов фіксованої, достатньо високої продуктивності - 8000 кг молока на корову в рік $[3,4,5]$. При цьому відкритим лишається питання оптимальності варіювання витрат в різних технологічних умовах у залежності від потужності підприємства. Це пов'язано із факторами змін усіх видів витрат (їх структури собівартості) при, наприклад, зростанні технологічного оснащення, яке призводить з одного боку до економії трудових, енергетичних та інших матеріальних ресурсів, а, разом з тим, у наслідок використання інноваційних технологічних рішень зростають амортизаційні відрахування та витрати ресурсів, що пов'язані з утриманням будівель та обслуговуванням стада [6].

Таблиия 1

Фактичне поголів'я (на прикладі Харківській області), тис. голів

\begin{tabular}{|c|c|c|c|c|c|}
\hline Поголів'я у різних типах підприємств & $2015 p$. & $2016 \mathrm{p}$. & $2017 p$. & $2018 p$. & $2019 p$. \\
\hline Велика рогата худоба, всього & 192,1 & 195,8 & 194,2 & 187,9 & 180,8 \\
\hline у т.ч.: у с.-г. підприємствах & 96,9 & 97,4 & 95,7 & 88,2 & 88,7 \\
\hline з них фермерські господарства & 4,7 & 5,0 & 4,6 & 4,6 & 4,8 \\
\hline господарства населення & 95,2 & 98,4 & 99,0 & 99,7 & 92,1 \\
\hline Корови, всього & 92,7 & 91,8 & 91,1 & 88,3 & 87,7 \\
\hline у т.Ч.: у с.-г. підприємствах & 37,3 & 36,4 & 35,8 & 33,9 & 34,5 \\
\hline з них фермерські господарства & 1,8 & 1,9 & 1,7 & 1,7 & 1,9 \\
\hline господарства населення & 55,4 & 55,4 & 55,3 & 54,4 & 53,2 \\
\hline Свині, всього & 296,6 & 299,8 & 235,7 & 166,5 & 194,8 \\
\hline у т.ч.: у с.-г. підприємствах & 181,3 & 185,5 & 123,8 & 64,8 & 99,1 \\
\hline з них фермерські господарства & 3,3 & 3,4 & 3,0 & 0,8 & 1,4 \\
\hline господарства населення & 115,3 & 114,3 & 111,9 & 101,7 & 95,7 \\
\hline Вівці і кози, всього & 74,3 & 74,3 & 72,9 & 72,3 & 71,0 \\
\hline у т.ч.: у с.-г. підприємствах & 11,3 & 9,0 & 6,3 & 6,0 & 6,8 \\
\hline з них фермерські господарства & 2,2 & 1,3 & 1,0 & 1,1 & 1,5 \\
\hline господарства населення & 63,0 & 65,3 & 66,6 & 66,3 & 64,2 \\
\hline Вівці, всього & 36,6 & 35,2 & 32,7 & 32,2 & 32,1 \\
\hline у т.ч.: у с.-г. підприємствах & 10,7 & 8,4 & 5,7 & 5,4 & 5,2 \\
\hline господарства населення & 25,9 & 26,8 & 27,0 & 26,8 & 25,9 \\
\hline Коні, всього & 2,4 & 2,1 & 2,1 & 2,1 & 1,8 \\
\hline у т.ч.: у с.-г. підприємствах & 0,8 & 0,7 & 0,7 & 0,7 & 0,4 \\
\hline господарства населення & 1,6 & 1,4 & 1,4 & 1,4 & 1,4 \\
\hline Птиця, всього & 8737,7 & 7485,3 & 6869,3 & 7543,2 & 8021,9 \\
\hline у т.Ч.: у с.-г. підприємствах & 4189,3 & 2706,4 & 2035,4 & 2613,8 & 3147,4 \\
\hline з них фермерські господарства & 3,3 & 2,9 & 3,5 & 3,4 & 2,7 \\
\hline господарства населення & 4548,4 & 4778,9 & 4833,9 & 4929,4 & 4874,5 \\
\hline Кролі, всього & 240,4 & 234,6 & 227,1 & 240,0 & 240,8 \\
\hline у т.ч.: у с.-г. підприємствах & 6,9 & 6,7 & 4,7 & 4,2 & 3,3 \\
\hline господарства населення & 233,5 & 227,9 & 222,4 & 235,8 & 237,5 \\
\hline Бджоли, всього & 130,6 & 126,5 & 124,4 & 123,2 & 113,5 \\
\hline у т.ч.: у с.-г. підприємствах & 3,9 & 3,5 & 3,3 & 2,8 & 3,0 \\
\hline господарства населення & 126,7 & 123,0 & 121,1 & 120,4 & 110,5 \\
\hline
\end{tabular}

Перехід від одного рівня виробничих потужностей до більше високого потребує зміни системи технологічних рішень, які набувають якісних ознак. За умов такого переходу ці зміни пов'язані, перш за все, з граничними витратами на організацію технологічного процесу. Тому, виникає необхідність аналізу типів підприємств за умов як різної продук- тивності корів, так і виробничої потужності з урахуванням побудови технологічних процесів.

Матеріали та методи досліджень. Методи дослідження - статистико-економічний - для опрацювання масиву статистичних та емпіричних даних; монограсфічний - для детального вивчення окремих елементів досліджуваного 
явища на прикладі конкретних об'єктів; розрахунковий - для розробки та визначення параметрів. Теоретичною та методологічною основою для проведення досліджень були офіційні матеріали управління статистики областей та районів, законодавчі і нормативні акти органів державної влади України з питань розвитку АПК, положення економічної теорії, праці вітчизняних і зарубіжних вчених з проблем розвитку аграрного сектора. За загальноприйнятими $[7,8]$ і спеціальною методикою [9] проведено нелінійний трьохфакторний регресійний аналіз, який дозволив одержати для кожного варіанту потужності специфічну цільову функцію залежності загальних витрат (Y) від продуктивності (X1), поголів'я (X2) і змінних витрат (X3).

Результати досліджень. Дослідження проведено на фактичних матеріалах сільськогосподарських підприємств Харківської області з річним виробництвом молока за трьома варіантами виробничої потужності. Перший - невеликі, всього 90 господарств до 20 тис. ц, у тому числі 9 господарств $з$ потужністю 16-20 тис. ц, Другий - середні, всього 22 господарства до 60 тис. ц, у тому числі 18 господарств 3 потужністю 24-58 тис. ц, з них ДП ДГ «Гонтарівка» (36 тис. ц) мережі НААН. Третій - великі, всього 9 господарств до 100 тис. ц (70-95 тис. ц).

Для всіх варіантів проведено оцінку значущості основних видів витрат за наступними елементами: оплата праці; відрахування на соціальні заходи; корми; засоби захисту тварин; паливо та мастила; електроенергія; амортизація; поточний ремонт; роботи та послуги; інші матеріальні витрати; загальновиробничі витрати згідно методів економетрики [7].

За визначеними трендами змін кількісних характеристик по кожній градації встановлено ступінь впливу досліджуваних фракторів в умовах ключових параметрів підприємств з виробництва молока різної виробничої потужності на ефективність їх діяльності.

Визначені фрактори-лідери впливу на загальні витрати (за критерієм максимальної кореляції з відгуком або максимальним значенням критерію Фішера [8], якими стали продуктивність, поголів'я корів та сума змінних витрат, основна значущість серед яких належить витратам на корми. На основі цього за розробленою методикою оптимізації технолого-економічних параметрів підприємств різної виробничої потужності проведено нелінійний багатофакторний регресійний аналіз, який дозволив одержати для різних типів підприємств специфічну цільову функцію залежності загальних витрат від продуктивності, поголів'я і змінних витрат [9].

Алгоритм екстраполяції для кожного варіанту групування дозволяє прогнозувати загальні витрати у межах граничних параметрів обмежень визначальних вихідних факторів. На цьому принципі обчислені конкретні рівняння множинної нелінійної регресії для обраних градацій групувань (рис. 1).

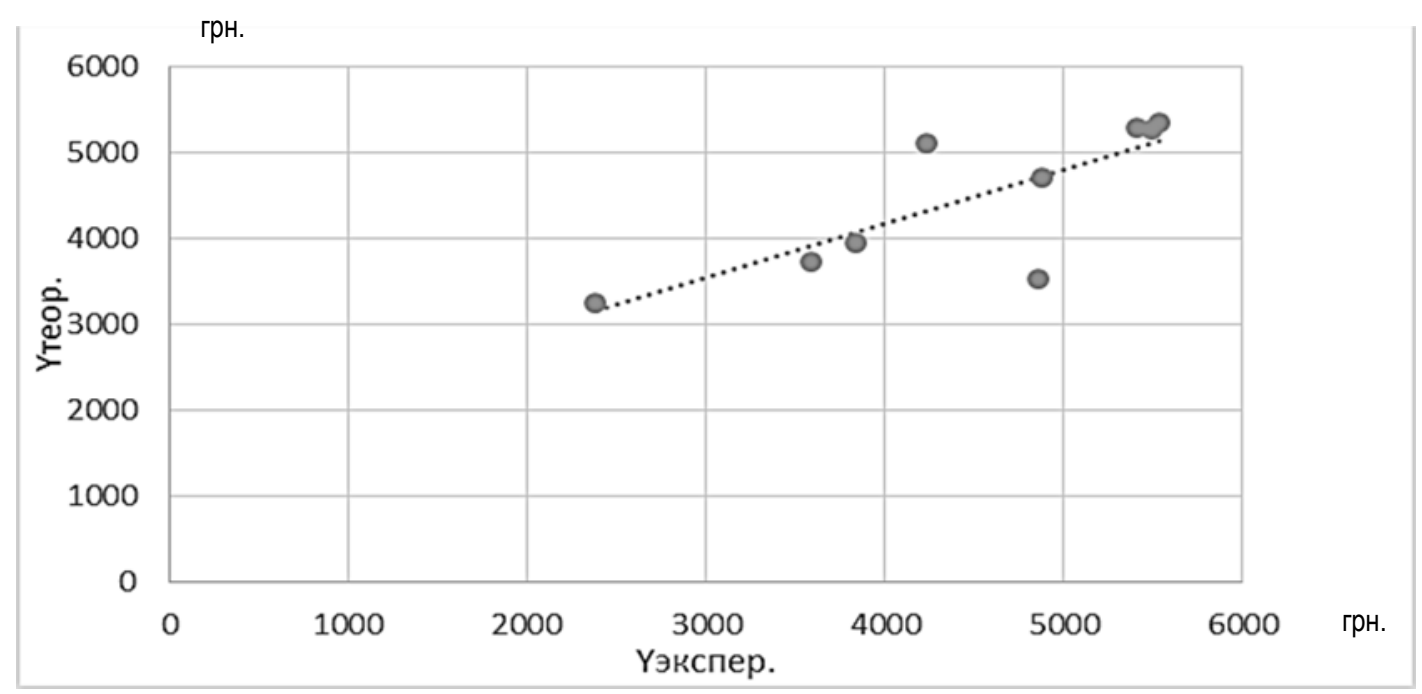

Рисунок 1 - Оцінка прогнозу при $\mathrm{R}^{2}=0,6153$.

Рівняння множинної нелінійної регресії за розробленою методикою для підприємств малої виробничої потужності (до 20 тис. ц) має наступний вигляд:

$Y=4468,233^{*}[-1 E-07(X) \wedge 2+0,0007(X 3)+0,0343]^{*}[$ $6 \mathrm{E}-09(\mathrm{X} 1)^{\wedge} 2-$

$-9 \mathrm{E}-05(\mathrm{X} 1)+1,2405]^{*}\left[6 \mathrm{E}-07(X 2)^{\wedge} 2-0,0008(X 2)+\right.$ $1,2063]+(25,44907)$.

Коефріцієнти нелінійної моделі значимі (ці коефріцієнти формуються під впливом невипадкових фракторів), коефріцієнт множинної кореляції Rмн. $=0,784404$ досить високий (тісний зв'язок між розглянутими ознаками). Для перевірки адекватності рівняння регресії використано середню відносну помилку прогнозування (апроксимації), яка становить $10,1 \%$. Це показує, що саме ця залежність найкраще описує вихідний параметр (Y) - собівартість молока залежно від продуктивності корів, поголів'я та вартості змінних витрат.

Гістограма залишків характеризує відхилення значень змінних витрат від прогнозованого за рівнянням множинної регресії (рис. 2). 


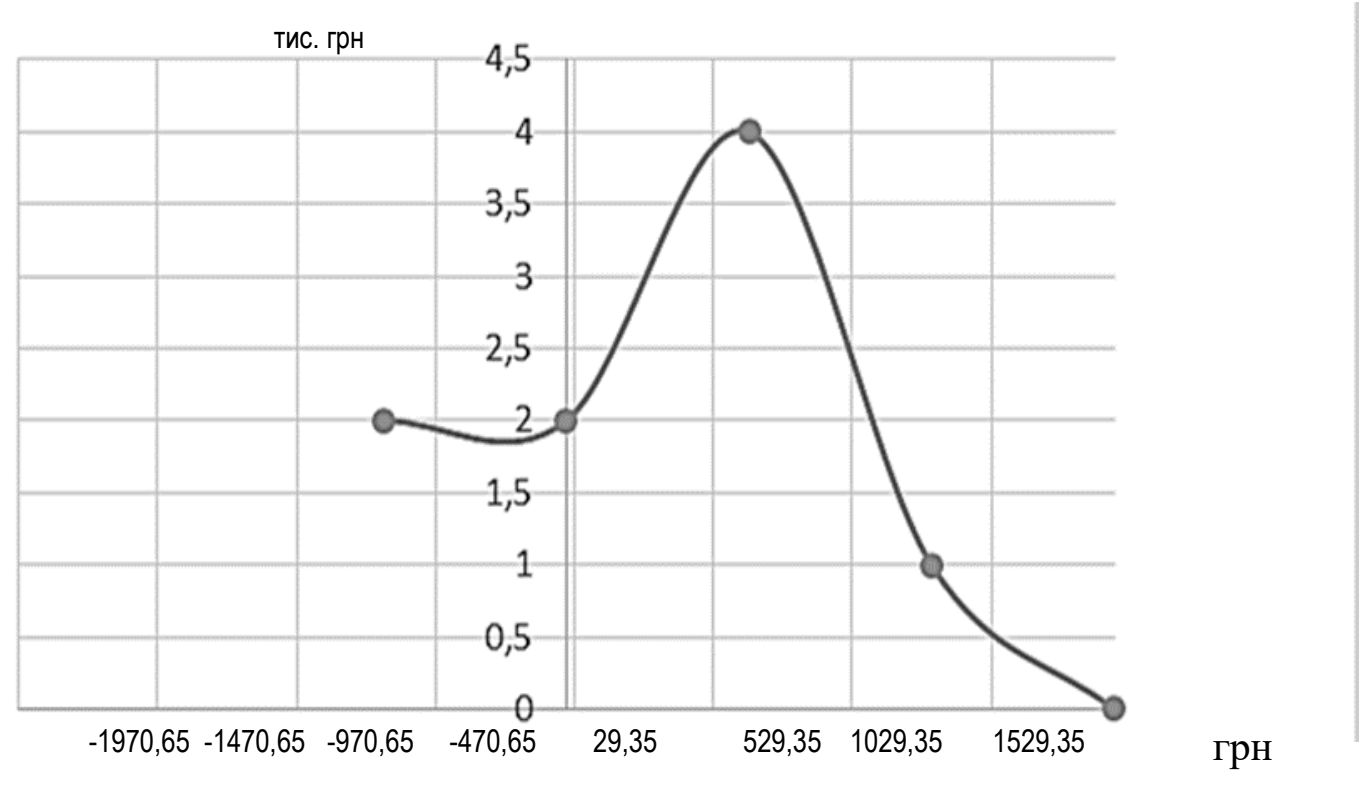

Рисунок 2 - гістограма залишків змінних витрат.

При розрахунку рівняння були прийняті обмеження за продуктивністю від 2476 до 7751 кг молока на корову за рік, за поголів'ям від 240 до 790 голів, за обсягом змінних витрат від 1317 до 3390 тис. грн. В результаті рішення отримано оптимальний рівень собівартості 3259 тис. грн при продуктивності 7147 кг молока з поголів'ям 280 корів.
Рівняння множинної нелінійної залежності за розробленою методикою для підприємств середньої виробничої потужності (20-60 тис. ц) має наступний вигляд (рис. 3).

$Y=9953,15^{*}\left[6 \mathrm{E}-09(\mathrm{X} \mathrm{3})^{\wedge} 2+6 \mathrm{E}-05(\mathrm{X} 3)+0,5004\right]^{*}[$ $\left.0,7354 \mathrm{e}^{\wedge}[0,0006(\mathrm{X} 2)]\right]^{*}$

${ }^{*}\left[1 \mathrm{E}-08(\mathrm{X} 1)^{\wedge} 2-0,0002(\mathrm{X} 1)+1,9693\right]+(-842,856)$.

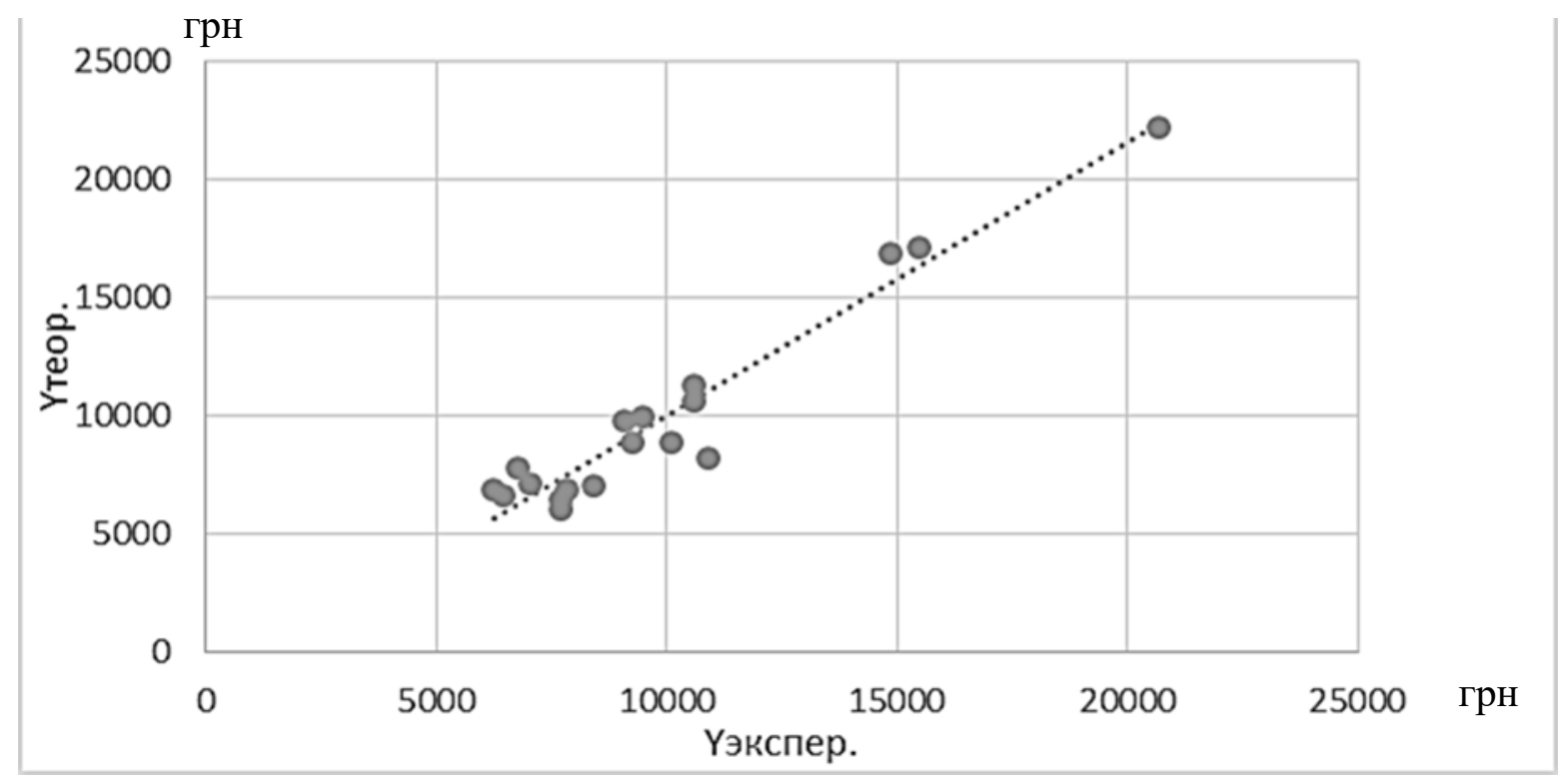

Рисунок 3 - Оцінка прогнозу при $\mathrm{R}^{2}=0,9337$.

Відхилення значень змінних витрат від прогнозова- $\mid$ потужністю від 20 до 60 тис. ц молока в рік характеризує ного за рівнянням множинної регресії для підприємств з 


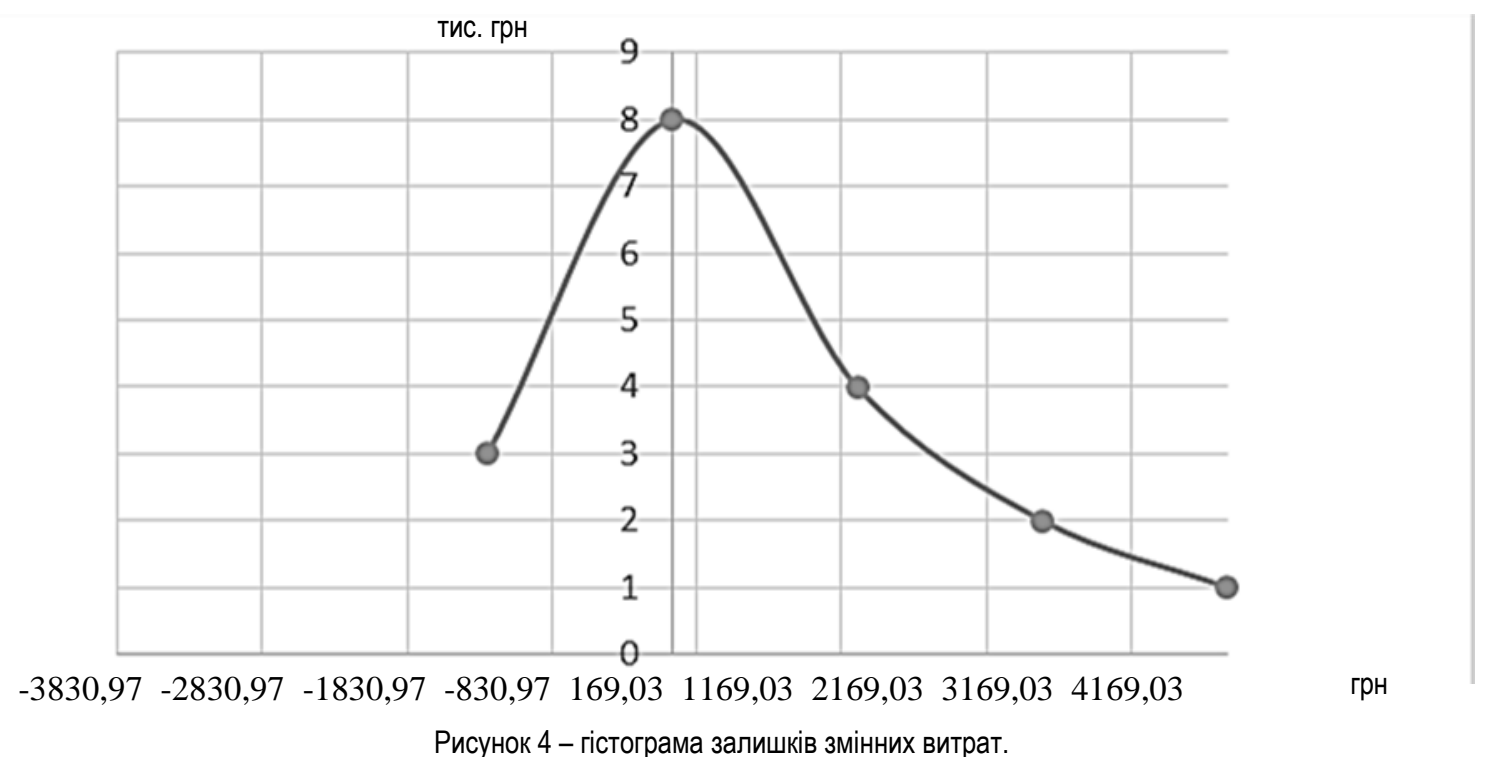

Коесріцієнт множинної кореляції одержаної моделі для підприємств середньої потужності високий Rмн. $=0,966271$. Середня відносна помилка апроксимації становить 10,504\%.

При розрахунку рівняння були прийняті обмеження за продуктивністю від 5022 до 9916 кг молока на корову за рік, за поголів'ям від 300 до 1014 голів, за обсягом змінних витрат від 2413 до 10680 тис. грн. В результаті рішення отримано оптимальний рівень собівартості 7096 тис. грн за продуктивності 9870 кг молока з поголів'ям 608 корів.

Рівняння множинної нелінійної залежності за розробленою методикою для підприємств великої виробничої потужності (60-100 тис. ц) має наступний вигляд (рис. 5):

$Y=22364^{*}\left[-6 \mathrm{E}-09(X 3)^{\wedge} 2+0,0002(X 3)-0,3108\right]^{*}[9 E-$ $07(X 2)^{\wedge} 2-$

$-0,0021(X 2)+2,0029]^{\star}\left[1 E-08(X 1)^{\wedge} 2-0,0002(X 1)+\right.$ $1,5453]+(8944,266)$.

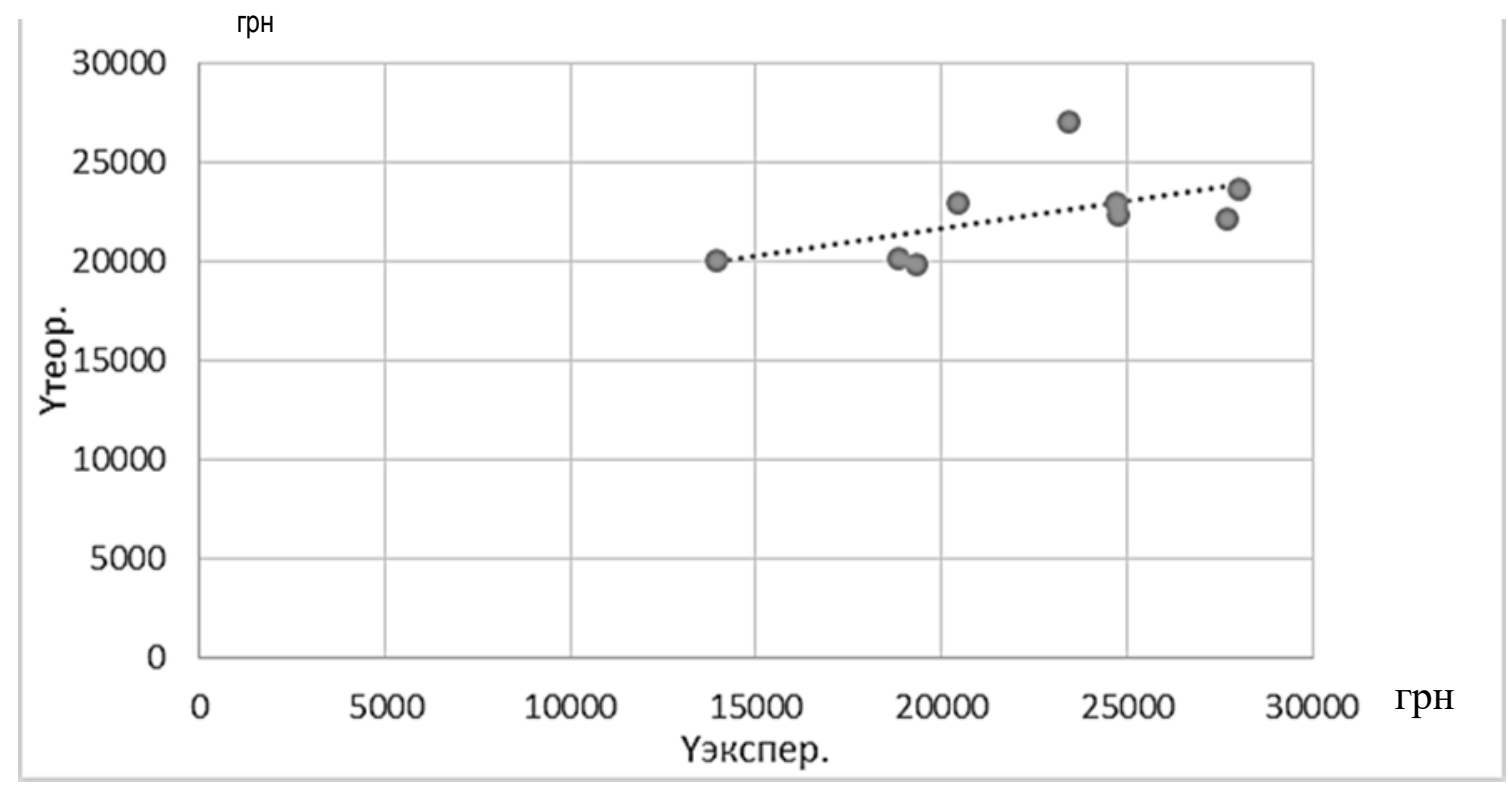

Рисунок 5 - Оцінка прогнозу при $\mathrm{R}^{2}=0,3137$.

Відхилення значень змінних витрат від прогнозованого за рівнянням множинної регресії для підприємств 3

потужністю від 60 до 100 тис. ц молока в рік характеризує гістограма залишків (рис. 6). 


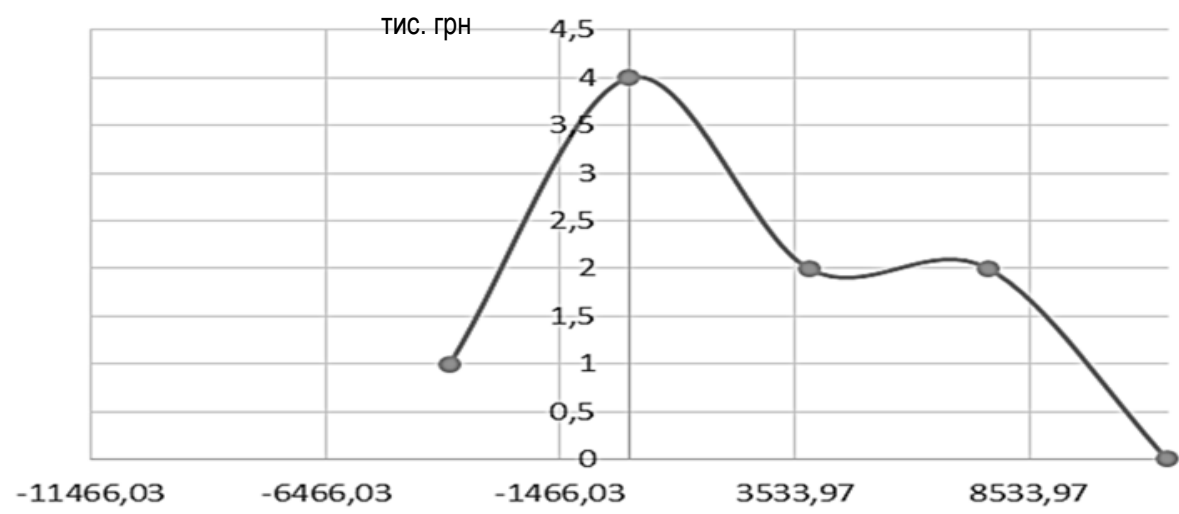

Рисунок 6 - гістограма залишків змінних витрат.

Коефріцієнт множинної кореляції одержаної моделі для підприємств великої потужності Rмн. $=0,56011$ середній. Середня відносна помилка апроксимації становить 13,942\%.

При розрахунку рівняння були прийняті обмеження за продуктивністю від 4584 до 10136 кг молока на корову за рік, за поголів'ям від 620 до 1540 голів, за обсягом змінних витрат від 7506 до 16935 тис. грн. В результаті рішення отримано оптимальний рівень собівартості 17182 тис. грн за продуктивності 9321 кг молока з поголів'ям 1073 корів.

Одержані результати покладено в основу розробленої методики оптимізації технолого-економічних параметрів підприємств різної виробничої потужності.

Методика розкриває алгоритм дій при оцінці комплексу різних факторів впливу на залежний від них чинник для його оптимізації (максимізації, мінімізації або набуття визначеного значення, залежно від цільової функції). Алгоритм побудовано на методах статистичного аналізу з використанням лінійних і нелінійних функцій який дозволяє оцінити значимість регресійних рівнянь за умов невідомої і не рівної дисперсії рядів спостережень даних (за критерієм Фішера) 3 визначенням похибки помилки апроксимації. Алгоритм дозволяє визначити по-шагові розрахунки проміжних регресійних рівнянь, коефіцієнти множинної кореляції, множинний критерій Фішера, його табличне значення та графічне представлення результату. Остаточний шаг розрахунку дає оцінку про нормальність розподілу залишків (помилку прогнозу) за критерієм перевищення помилки репрезентативності асиметрії і ексцесу у межах їх 3-кратної похибки із надан- ням висновку про перевищення (або навпаки) критичного порогу, коли гіпотеза про нормальний розподіл залишків (помилка прогнозу) відхилена або вона приймається. Гістограма залишків наочно дає уяву про їх розподіл.

Розроблений алгоритм, дає можливість універсально обчислювати і оцінювати багатофакторні нелінійні моделі прогнозу за умов коли кореляційний зв'язок між ознаками низький [9].

Висновки. 1. За визначеними фактичними величинами середніх і граничних витрат і власне розробленою методикою визначені рівняння множинної нелінійної регресії для підприємств малої виробничої потужності (до 20 тис. ц), середньої (від 20 до 60 тис. ц) і великої потужності (від 60 до 100 тис. ц). Коефіцієнт множинної кореляції між впливовими ознаками (продуктивність, чисельність поголів'я і змінні витрати) відповідно становить Rмн.=0,784404; Rмн. $=0,966271$ та Rмн. $=0,56011$. Середня відносна помилка апроксимації дорівнює 10,1%; 10,5 \% і 13,9 \% відповідно.

2. Розроблений методичний підхід розкриває принципи механізмів щодо вирішення проблем оптимізації багатофакторних нелінійних моделей прогнозу, за умов коли кореляційний зв'язок між ознаками низький, дає можливість універсально оцінювати і обчислювати закономірності взаємодії будь-яких впливових чинників і отримувати їх кількісні характеристики шляхом розрахунку рівнянь множинної нелінійної регресії на фактичних даних з подальшим аналізом одержаних функціональних залежностей.

\section{Список використаної літератури:}

1. Державна служба статистики України «Тваринництво України». Статистичний збірник. Київ, 2019, 168 с.

2. Бащенко М.І. та ін. Тваринництво України: стан, проблеми, шляхи розвитку (1991-2017-2030рр.): монограсрія. К.: «Аграрна наука», 2017. 160 с.

3. Річні нормативи заготівлі та структури кормів для різних видів тварин в залежності від їх продуктивності по зонах України: нормативний науково-виробничий посібник (3-є видання доповнене). Інститут тваринництва УААН, Харків, 2008, 31 c.

4. Помітун І.А., Марченко В.А., Адмін О.Є. та ін. Техніко-економічні параметри та планувальні рішення реконструкції і нового будівництва молочних ферм: довідник. Інститут тваринництва УААН, Харків, 2016. 374 с.

5. Марченко В.А., Бовсуновский В.В., Миненко К.В., Канцевич С.И. Обоснование технолого-экономических параметров молочных ферм и комплексов различной производственной мощности. Актуальне проблемы інтенсивного развития животноводства: сб. науч. тр. Горки: БГСХА, 2018. Вып. 21. Ч. 2. С.166-171.

6. Бібік О.В., Марченко В.А., Германенко О.М. Оптимізація витрат як засіб підвищення прибутковості підприємства. Збірник матеріалів Звітної наук.-практ. конф. Луганського національного аграрного університету .(Харків, 28.02-01.03.2019). ЛНАУ. Х.: ФОП Бровін О.В., 2019. С.72-75.

7. Гетманец О.М. Эконометрика: курс лекций для студентов факультета менеджмента, обучающихся по направлению 